\title{
Synthesis and thermal studies of flexible polyurethane nanocomposite foams obtained using nanoclay modified with flame retardant compound
}

\author{
Łukasz Piszczyk • Magdalena Danowska • \\ Anna Mietlarek-Kropidłowska • Magdalena Szyszka • \\ Michał Strankowski
}

Received: 31 October 2013/Accepted: 16 May 2014/Published online: 24 August 2014

(C) The Author(s) 2014. This article is published with open access at Springerlink.com

\begin{abstract}
This work presents thermal studies of nanocomposites based on the flexible polyurethane (PU) matrix and filled using montmorillonite organically modified with organophosphorus flame retardant compound. Flexible PU nanocomposite foams were prepared in the reaction carried out between reactive alcoholic hydroxyl and isocyanate groups with the ratio of $\mathrm{NCO}$ to $\mathrm{OH}$ groups equal to 1.05 . The amount of an organoclay ranging from 3 to 9 vol\% was added to the polyol component of the resin before mixing with isocyanate. The apparent density of PU foams was ranging from 0.066 to $0.077 \mathrm{~g} \mathrm{~cm}^{-1}$. Thermal properties of the flexible PU nanocomposite foams were investigated by thermogravimetry and dynamical mechanical analysis. Glass transition temperatures $\left(T_{\mathrm{g}}\right)$ were defined as maximum peak on $\tan \delta$ curve. Thermal decomposition was observed at $310-320{ }^{\circ} \mathrm{C}$ (calculated from the onset of TG curve). Tensile strength of the PU foams was determined using mechanical test. The microstructure of the nanoparticles and the composites was investigated by X-ray diffraction. Finally, it was confirmed
\end{abstract}

Ł. Piszczyk · M. Szyszka · M. Strankowski

Department of Polymer Technology, Chemical Faculty, Gdansk University of Technology, 11/12 Narutowicza Str., 80-233 Gdansk, Poland

\section{Danowska}

Solid State Physics Department, Faculty of Applied Physics and Mathematics, Gdansk University of Technology, 11/12

Narutowicza Str., 80-233 Gdansk, Poland

\section{A. Mietlarek-Kropidłowska ( $\square)$}

Department of Inorganic Chemistry, Chemical Faculty, Gdansk University of Technology, 11/12 Narutowicza Str., 80-233 Gdansk, Poland

e-mail: anna.mietlarek-kropidlowska@pg.gda.pl that the thermal and mechanical properties of flexible PU nanocomposite depend on the amount of nanoclay.

Keywords Glass transition, thermal stability . Polyurethane foams - Layered silicate nanoclay . Flammability · Dynamical thermal analysis

\section{Introduction}

Polyurethane-based materials have found widespread use in different branches of industry. Variety of processing methods and products' versatility depending on the PU chemical structure and addition of the modifiers result in growing interest in this group of materials. It is one of the reasons why we search for the new modifiers that could improve the properties of products with the minimum expenditure of costs (the use of small amounts of modifying agents, low price of compounds). Thus, nowadays, a lot of attention is paid to nanofillers, mainly from the aluminosilicate group, called montmorillonites (MMT).

Polymer-MMT nanocomposites are the most common class of nanocomposites and the one which has been lately widely investigated [1-4]. Because of the dispersion at the nanometer level, polymer-clay nanocomposites exhibit superior properties in comparison with the pure polymers or conventional composites. These properties include lightweight [5], high modulus, enhanced physicalmechanical strength [6, 7], improved gas barrier [8], increased solvent resistance [9], improved thermal stability, and flame retardancy [10, 11]. Another impressive feature of nanocomposites and nano-filled composites is the concurrent improvement of multiple properties, in addition to the introduction of new functionalities [12]. The mechanical properties of nanocomposites are superior to 
the fiber-reinforced polymers because enhancement from the inorganic layers occurs in three dimensions rather than only in the dimension of the fiber [13]. The improvement in thermal stability of polymer-clay nanocomposites is due to the nano-sized layers restricting the polymer molecular chain motion $[14,15]$.

Polymer foams are a class of cellular materials that possess distinctive mechanical, physical, and thermal properties and are, therefore, attractive engineering materials. Polymer foams consist of two phases, a solid phase and a gas phase, and can be categorized as flexible, semirigid, or rigid, depending on their chemical composition and degree of cross-linking. Foams are also broadly classified as closed cell foams, when the dispersed gas cells are completely enclosed by cell walls, or open cell foams, when the cells are unconfined and connected by open passages [16].

Polyurethane foams (PUFs) are generated via mixing, foaming, and cross-linking of mixtures of polyols and dior triisocyanates with blowing agents and activators. PUFs have a highly significant place among other synthetic materials. They are widely used in the rigid, elastic, and integral form as well as after a possible directional modification by changing the foam composition, component mass ratios, and processing conditions. Depending on their composition, polyurethane foams can be characterized by high mechanical resistance, vibration-reducing properties, particular resistance to weather conditions, and resistance to organic solvents and oils. Polyurethane foams have found application in many branches of industry such as construction, furniture production, automotive production, clothing manufacturing, and aviation [17].

The modification of polyurethanes using nanoclays improves numerous of their properties. The introduction of 10 mass \% of nanoclay into polyurethane elastomer leads to the increase in tensile strength, Young modulus, and elongation at rupture. Our previous studies showed that the modification of rigid PUFs with 6 mass\% of layered silicate gives $76 \%$ growth of the compression strength [18]. Introduction of nanoclays improves not only the mechanical properties, but also barrier characteristics-for example, the addition of 4 mass $\%$ of layered silicate reduces twice the oxygen permeability of thus obtained PUFs [19]. The permeability of polyurethane foams to water and dichloromethane is also decreased with the increasing content of nanoclay [20]. Even a small addition of nanoclay improves the thermal stability of polymer composite because silicate layers act as thermal insulation and because of the "labyrinth effect"- the sheets can serve as the barrier for the volatile species evolving during thermal degradation of the polymer material [21-25]. Introduction of up to 10 mass\% of nano-layered mineral silicates may cause the increase of the initial decomposition temperature
Table 1 Characteristics of polyols used

\begin{tabular}{rllll}
\hline Sample & $\begin{array}{l}\text { Density at } \\
25{ }^{\circ} \mathrm{C} / \\
\mathrm{g} \mathrm{cm}^{-3}\end{array}$ & $\begin{array}{l}\text { Molecular } \\
\text { mass/ } \\
\mathrm{g} \mathrm{mol}^{-1}\end{array}$ & $\begin{array}{l}\text { Hydroxyl } \\
\text { number/ } \\
\mathrm{mg} \mathrm{KOH} \mathrm{g}^{-1}\end{array}$ & Functionality \\
\hline $\begin{array}{r}\text { Rokopol } \\
\text { M1170 }\end{array}$ & 1.09 & 5,000 & $33-36$ & 3 \\
$\begin{array}{r}\text { Rokopol } \\
\text { F3000 }\end{array}$ & 1.01 & 3,000 & $53-39$ & 3 \\
\hline
\end{tabular}

even as much as over $15^{\circ} \mathrm{C}[19,26-28]$. This additives decrease also the rate of composites combustion [29]. However, despite advantages mentioned above, nanoclays do not guarantee incombustibility. The addition of layered silicates is insufficient to obtain materials incombustible during the vertical combustion test UL 94 [30, 31]. Therefore, the main goal of this work was the comparative analysis of the influence of montmorillonite organically modified with organophosphorus flame retardant compound and the mixture of montmorillonite and phosphorous flame retardant on the structure, mechanical properties, and the thermal stability of polyurethane foams.

\section{Experimental}

\section{Materials}

The polyols used in this study were commercial polyetherols: Rokopol M1170 and Rokopol F3000 (PCC Rokita, Poland), a general glycerol-based polyether polyols recommended for the production of flexible polyurethane foams. According to the manufacturer's report, density, molecular mass, and hydroxyl number are as follows in Table 1.

Other chemicals were also obtained from commercial sources and used as received: NIAX Silicone SR-393-a silicon-based surfactant (Momentive, Czech Republic); catalysts Dabco ${ }^{\circledR} 33-\mathrm{LV}-33$ mass\% solution of 1,4-diazobicyclo[2.2.2] octane in 2,2-dihydroxyisopropyl ether; and tin(II) 2-ethylhexanoate (Sigma-Aldrich), blowing agentsdistilled water.

Isocyanate: polymeric diphenylmethane-4,4'-diisocyanate (pMDI) characterized by $31 \%$ of NCO groups, the density of pMDI (at $25^{\circ} \mathrm{C}$ ) is $1.22 \mathrm{~g} \mathrm{~cm}^{-3}$.

The commercial nanoclay (Nanofil 116, a natural montmorillonite (MMT) by Southern Clay) and organophosphorus flame retardant (Fyrol PNX by ICL Industrial Products) were used to modify flexible polyurethane foams.

\section{MMT modification (m-MMT)}

To obtain modified hybrid nanoclay, the mixture of MMT and organophosphorus flame retardant (in 2:1 mass ratio) 


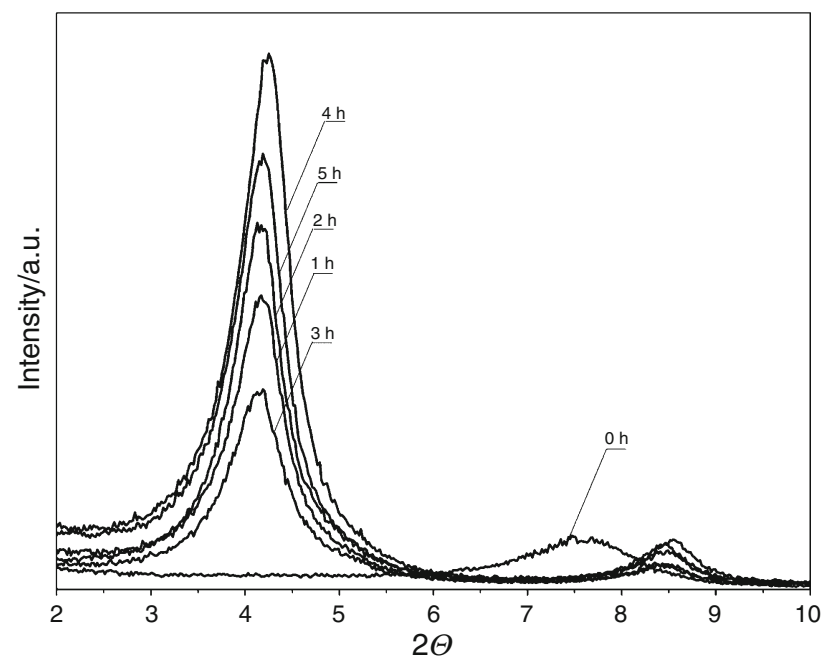

Fig. 1 XRD patterns of pure MMT $(0 \mathrm{~h})$ and modification MMT at different times of modification (1-5 h)

was homogenized at $60{ }^{\circ} \mathrm{C}$ using ultrasound bath. The optimum time of homogenization and the interlayer distance was determined according to XRD measurements, in which results are presented in Fig. 1. Diffractograms recorded for unmodified system and materials homogenized at specified time represent the dependence of interlayer distance on the time of the process. The 1-hour treatment resulted in the increase of the intergallery distance in MMT form 1.18 to $2.11 \mathrm{~nm}$, what corresponds to intercalation of the nanoclay plates together with the introduction of organophosphorus flame retardant molecules between MMT layers. Further increase of the time of the homogenization of mixture did not have distinct influence on the intergallery spacing.

\section{PU preparation}

The flexible polyurethane foams (f-PUF) were obtained in a laboratory scale in a single-step method from a twocomponent (A and B) system with a ratio of $\mathrm{NCO}$ and $\mathrm{OH}$ groups equal to 1.05 .

Component A (polyol mixture) consisted of oligoethersRokopol F3000, Rokopol M1170, catalysts, chemical blowing agents, and fillers (the latter at 3, 6 and 9 mass\%). It was prepared by vigorous stirring with a mechanical stirrer for $30 \mathrm{~min}$, and by sonication with an ultrasonic homogenizer for $20 \mathrm{~min}$. Next, nanoparticulated polyol matrix was mixed with the component B (polyisocyanate, pMDI), at a predetermined mass ratio, for $10 \mathrm{~s}$ at $3000 \mathrm{rpm}$. The resulting reaction mixture was poured into an open metal mold of approximate dimensions of $100 \times 50 \times 50 \mathrm{~mm}^{3}$. PUF samples, after demoulding, were stored at $60{ }^{\circ} \mathrm{C}$ for $24 \mathrm{~h}$, and seasoned at the room temperature for another $24 \mathrm{~h}$.
Modification of PUF using montmorillonite and organophosphorus flame retardant was carried out by the direct addition to polyol mixture (component A), the mixture of MMT with PNX (MMT/PNX), or previously modified montmorillonite using PNX (m-MMT).

The three systems were used to prepare 7 foam samples, as presented in Table 2 .

\section{Characterization}

X-ray diffraction (XRD)

$\mathrm{X}$-ray diffraction (XRD) measurements were performed using a Bragg-Brentano X'PERT PHILIPS diffractometer equipped with a $\mathrm{Cu}$ anode $\mathrm{X}$-ray tube and diffracted beam monochromator $(40 \mathrm{kV}, 30 \mathrm{~mA}, \lambda \mathrm{CuK} \alpha=0.1542 \mathrm{~nm})$. PUF samples were scanned in an angle ranging from $1.5^{\circ}$ to $10^{\circ}$.

\section{Scanning electron microscopy (SEM)}

The morphology of the polyurethane nanocomposite foams was examined using a Philips-FEI XL 30 ESEM scanning electron microscope operated at $10 \mathrm{kV}$ accelerating voltage. The skin layers of the foam blocks were removed, and the different samples were cut with a fresh scalpel perpendicular to the foam rise direction. The cell size of the different samples was measured from SEM micrographs, using image analysis software (Image J).

\section{Apparent density}

The densities of the PU nanocomposite foams were calculated according to ISO 845:2006 (E), from measurement of the dimensions and weight of the cubic samples.

Thermogravimetric analysis

Thermogravimetric measurements were carried out with the NETZSCH TG 209 F3 "Tarsus" using nitrogen atmosphere. The measurements were preformed from 50 to $600{ }^{\circ} \mathrm{C}$ at heating rate of $20^{\circ} \mathrm{C} \mathrm{min}^{-1}$.

\section{Tensile strength testing}

Tensile strength tests were carried out using a Zwick/Roell Z020 universal mechanical testing machine according to PN-EN ISO 1798:2008. Five samples of the different foams were cut, and the force was applied parallel to the foaming direction. The cross head speed was set $10 \mathrm{~mm} \min ^{-1}$ with a $1 \mathrm{~N}$ preload. 
Table 2 The composition of the reaction mixtures used to prepare flexible polyurethane foams with variable amounts of MMT/PNX and m-MMT

\begin{tabular}{|c|c|c|c|c|c|c|c|}
\hline \multirow{3}{*}{$\begin{array}{l}\text { Component } \\
\text { Sample no. }\end{array}$} & \multirow{3}{*}{$\begin{array}{l}\text { System } 1 \\
\text { content/\% } \\
P_{0}\end{array}$} & \multirow{2}{*}{\multicolumn{3}{|c|}{$\frac{\text { System } 2}{\text { content } / \%}$}} & \multirow{2}{*}{\multicolumn{3}{|c|}{$\frac{\text { System } 3}{\text { content } / \%}$}} \\
\hline & & & & & & & \\
\hline & & $P_{1}$ & $P_{2}$ & $P_{3}$ & $P_{4}$ & $P_{5}$ & $P_{6}$ \\
\hline Rokopol M1170 & 46.3 & 44.9 & 43.5 & 42.1 & 44.9 & 43.5 & 42.1 \\
\hline Rokopol F3000 & 19.8 & 19.2 & 18.6 & 18.0 & 19.2 & 18.6 & 18.0 \\
\hline NIAX Silicone SR-393 & 1.0 & 0.97 & 0.94 & 0.91 & 0.97 & 0.94 & 0.91 \\
\hline Dabco LV-33 & 0.3 & 0.29 & 0.28 & 0.27 & 0.29 & 0.28 & 0.27 \\
\hline Tin(II) 2-ethylhexanoate & 0.1 & 0.09 & 0.09 & 0.09 & 0.09 & 0.09 & 0.09 \\
\hline Water & 2.6 & 2.52 & 2.4 & 2.3 & 2.52 & 2.4 & 2.3 \\
\hline MMT (Nanofil 116) & - & 1.5 & 3.0 & 4.5 & - & - & - \\
\hline Fyrol PNX & - & 1.5 & 3.0 & 4.5 & - & - & - \\
\hline m-MMT & - & - & - & - & 3.0 & 6.0 & 9.0 \\
\hline pMDI & 29.9 & 29.0 & 28.1 & 27.2 & 29.0 & 28.1 & 27.2 \\
\hline
\end{tabular}

System 1: Unmodified flexible polyurethane foam (numbered 1 in Table 1)

System 2: f-PUF modified by Nanofil 116 and Fyrol PNX at 3, 6, and 9 mass\% (numbered 2-4 in Table 1)

System 3: f-PUF modified by m-MMT at 3, 6, and 9 mass\% (numbered 5-7 in Table 1)

The sample code consists of an index referring to clay type and a number defining mass $\%$ of clay, for example

$P_{0}$-unmodified flexible polyurethane foam

$P_{1}-P_{3}$-foam with 3-9 mass\% of MMT (Nanofil 116) and Fyrol PNX

$P_{4}-P_{6}$-foam with 3-9 mass\% of m-MMT

Dynamic mechanical analysis

The dynamical mechanical analysis (DMA) was carried out with a Q800 DMA instrument (TA Instruments, USA) with a heating rate of $3{ }^{\circ} \mathrm{C} \mathrm{min}{ }^{-1}$. The cylindrical shape of the sample size was $10 \times 10 \mathrm{~mm}^{3}$. The temperature range tested was from -80 to $20^{\circ} \mathrm{C}$. Storage modulus $\left(E^{\prime}\right)$ and loss modulus $\left(E\right.$ ") were obtained. Temperature $\left(T_{\mathrm{g}}\right)$ was taken as the peak temperature of $\tan \delta$ curve.

\section{Flammability}

Flammability of the foams was tested using UL-94 vertical burning test (flammability specification issued by the Underwriters Laboratories Inc.). This test measures the self-extinguishing time of the vertically oriented polymer specimen. The flame is brought into contact with the test specimen for $10 \mathrm{~s}$, after which the burner is removed.

\section{Results and discussion}

\section{Morphology}

The morphology of pure flexible polyurethane foams and the polyurethane nanocomposite foams was examined using scanning electron microscopy. Figures 2 and 3 show the microstructure of pure flexible polyurethane foam and the different types of modified foams obtained with 6 mass $\%$ of MMT/PNX and 6 mass\% of m-MMT. The sizes of foams' cells were measured from SEM micrographs, and the determined values are presented in Fig. 4.

The SEM micrographs show that the foams have a cellular structure with a round shape. All the foams consist of partially open cells, of varying size, with circular holes in the cell face (Fig. 3). The values of cell size are shown in Fig. 4. The unmodified flexible foam had a mean size of $216 \mu \mathrm{m}$. The cell size increase progressively with increasing fillers content. The cell sizes of foams modified by $\mathrm{m}-\mathrm{MMT}$ were 280,290 , and $266 \mu \mathrm{m}$, respectively, in the case of addition of 3,6 , and $9 \%$ of m-MMT to PUF. The cell size of foam modified by MMT/PNX was larger than in the case of the ones obtained using m-MMT filler. It is most probably caused by the addition of organophosphorus flame retardant, Fyrol PNX, which plasticizes the foam system, thus leading to the growth of the cells.

\section{Mechanical properties}

The results of density, tensile strength ( $T \mathrm{sb})$, and elongation at break $\left(E_{\mathrm{b}}\right)$ are shown in Table 3 . The density of the pure polyurethane foam was $66 \mathrm{~kg} \mathrm{~m}^{-3}$. The density increased to $77 \mathrm{~kg} \mathrm{~m}^{-3}$ in the case of the system modified with 9 mass\% of MMT/PNX and also increased to 

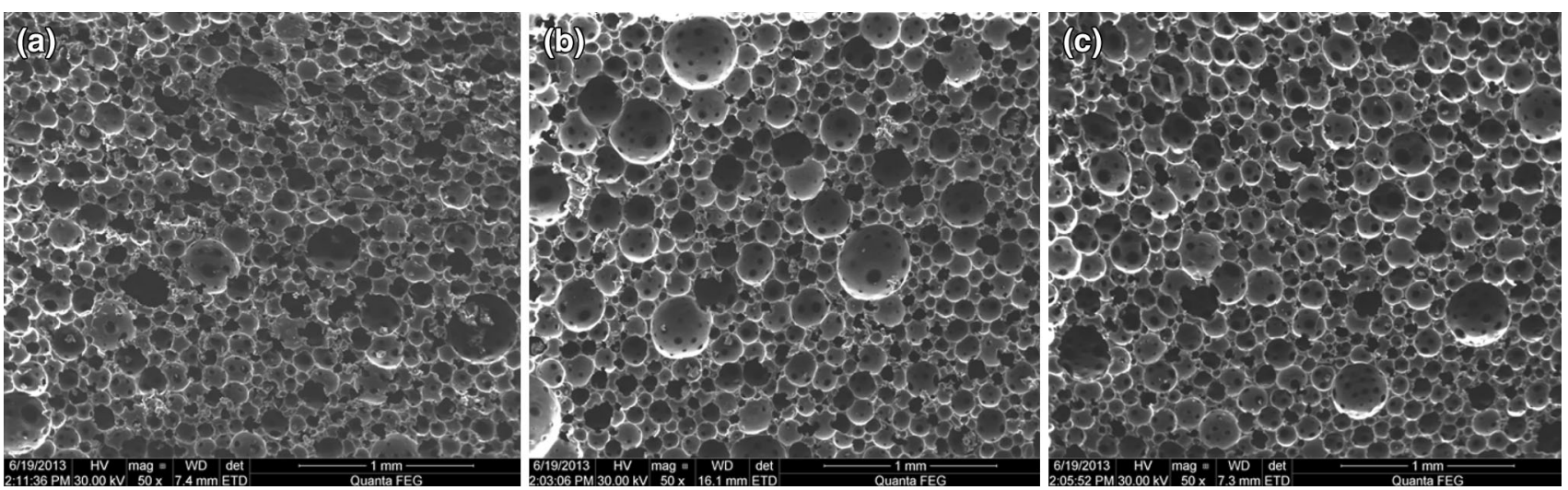

Fig. 2 SEM micrograph of pure foam PUF a, foam modified with $6 \%$ MMT/PNX b, PUF modified with $6 \%$ m-MMT c
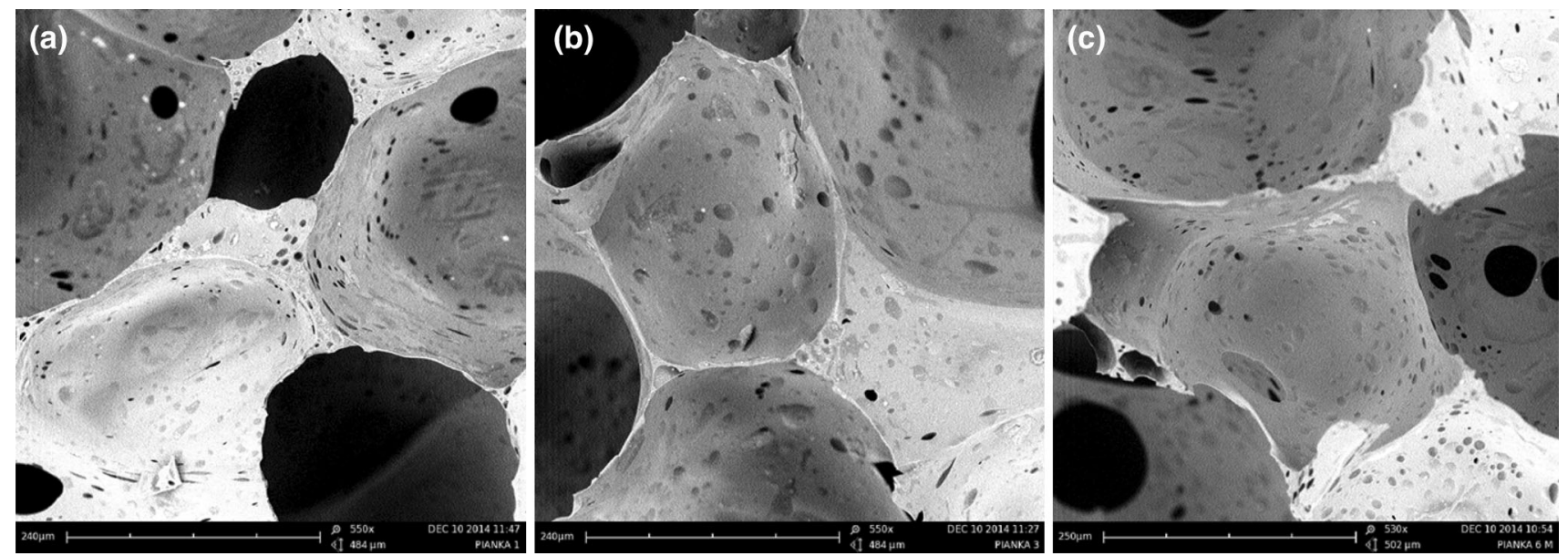

Fig. 3 Higher magnification SEM micrograph of pure foam PUF a, PUF modified by $6 \%$ MMT/PNX b, foam modified by $6 \%$ m-MMT c

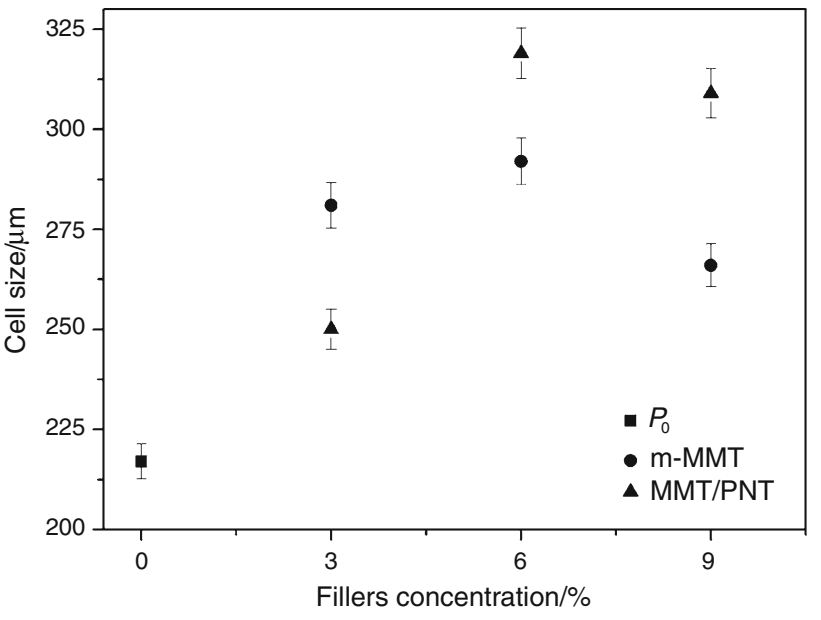

Fig. 4 Cell size of pure foam and the foam modified by PNX/MMT and $\mathrm{m}-\mathrm{MMT}$
Table 3 Apparent density and tensile strength of flexible polyurethane foams

\begin{tabular}{llrl}
\hline Sample & Density $/ \mathrm{kg} \mathrm{m}^{-3}$ & $T \mathrm{~s}_{\mathrm{b}} / \mathrm{kPa}$ & $E_{\mathrm{b}} / \%$ \\
\hline$P_{0}$ & $66 \pm 3$ & $106 \pm 3$ & $83 \pm 2$ \\
$P_{1}$ & $69 \pm 3$ & $112 \pm 3$ & $84 \pm 2$ \\
$P_{2}$ & $73 \pm 4$ & $100 \pm 3$ & $76 \pm 2$ \\
$P_{3}$ & $77 \pm 4$ & $104 \pm 3$ & $80 \pm 2$ \\
$P_{4}$ & $68 \pm 3$ & $133 \pm 4$ & $92 \pm 3$ \\
$P_{5}$ & $70 \pm 3$ & $97 \pm 3$ & $81 \pm 2$ \\
$P_{6}$ & $74 \pm 4$ & $85 \pm 2$ & $75 \pm 2$ \\
\hline
\end{tabular}

$74 \mathrm{~kg} \mathrm{~m}^{-3}$ for 9 mass\% m-MMT. This behavior is considered to be due to the opposing effect of nanoparticle addition on nucleation and cell growth. The nanoparticles act as nucleation sites promoting the formation of higher 

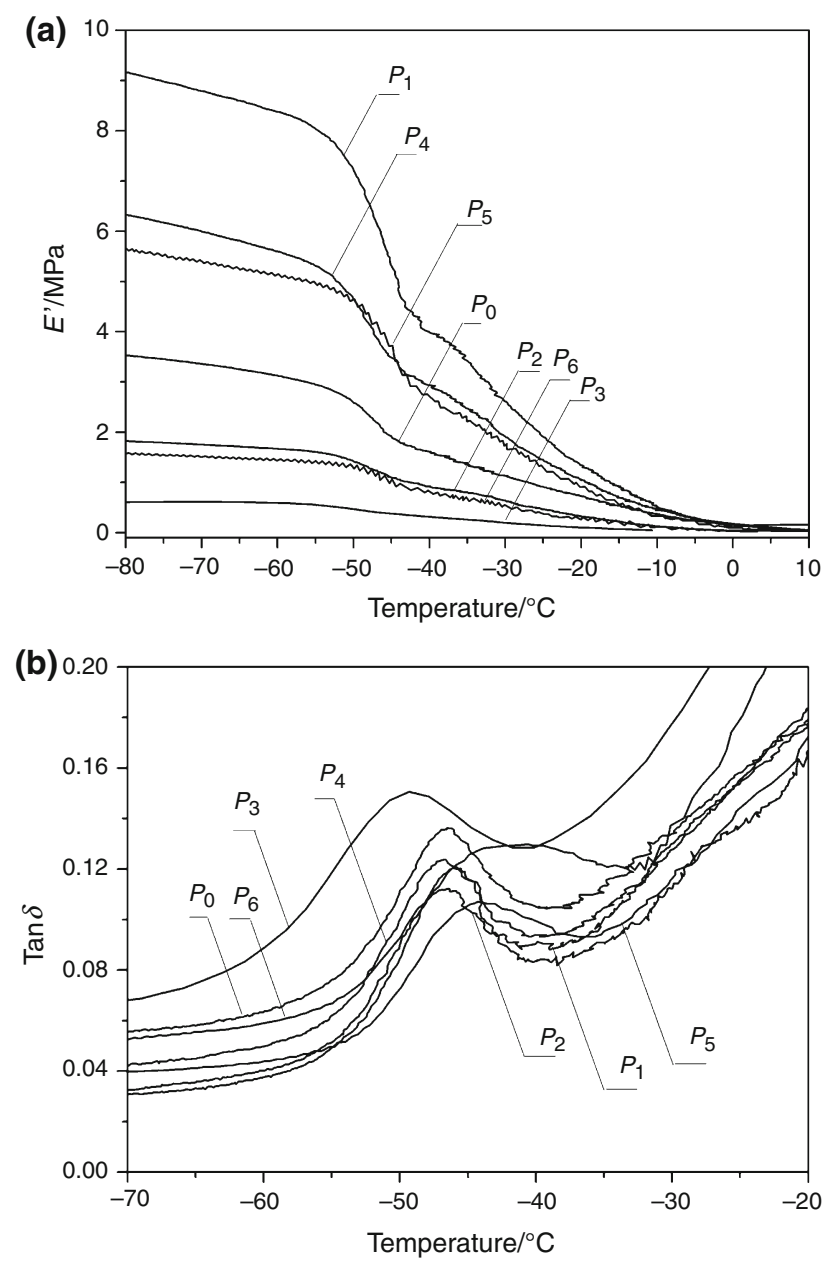

Fig. 5 Storage modulus $E^{\prime} \mathbf{a}$ and $\tan \delta \mathbf{b}$ as a function of temperature

quantity of bubbles, and this trends to increase with the nanoparticles content, but at the same time, growth of the resulting cells seems to be hindered by the increase in viscosity. The increase in apparent density in foams modified with nanofillers has been reported elsewhere [32-36].

The tensile strength of unmodified flexible polyurethane foam is $106 \mathrm{kPa}$, and the elongation at break is $83 \%$. Introduction of 3 mass\% of modifiers (MMT/PNX and $\mathrm{m}$-MMT) to PUF results in the increase of tensile strength and elongation at break. Addition of larger amounts of modifiers in f-PUS caused decrease of these parameters.

\section{Dynamic mechanical analysis}

The glass transition and storage modulus of pure flexible polyurethane foam and the polyurethane nanocomposite foams were examined using DMA. Figure 5 shows the storage modulus $E^{\prime}$ and $\tan \delta$ curves as a function at temperature. The values of $E^{\prime}$ modulus in specified temperatures and temperature and glass transition $T_{\mathrm{g}}$ for pure foam and nanocomposite foams are presented in Table 4.
Table 4 Values of E' modulus in characteristic temperatures and glass transition temperature $\left(T_{\mathrm{g}}\right)$ of pure foam and nanocomposite foams

\begin{tabular}{llllll}
\hline Sample & $T_{\mathrm{g}}{ }^{\circ} \mathrm{C}$ & \multicolumn{5}{l}{ Temperature $/{ }^{\circ} \mathrm{C}$} \\
\cline { 3 - 6 } & & -70 & -30 & -10 & $\tan \delta_{\max }$ \\
& & $E^{\prime} / \mathrm{MPa}$ & & & \\
\hline$P_{0}$ & -46 & 3.35 & 1.14 & 0.34 & 0.13 \\
$P_{1}$ & -45 & 8.81 & 2.59 & 0.56 & 0.12 \\
$P_{2}$ & -46 & 1.76 & 0.63 & 0.12 & 0.11 \\
$P_{3}$ & -49 & 0.62 & 0.18 & 0.04 & 0.15 \\
$P_{4}$ & -46 & 6.00 & 1.92 & 0.48 & 0.12 \\
$P_{5}$ & -43 & 5.41 & 1.77 & 0.34 & 0.10 \\
$P_{6}$ & -42 & 1.51 & 0.33 & 0.12 & 0.13 \\
\hline
\end{tabular}

The glass transition temperature was determined according to the maximum of the peak on $\tan \delta$ curve. The $T_{\mathrm{g}}$ of the unmodified flexible polyurethane foam is $-46{ }^{\circ} \mathrm{C}$. The addition of 3 and 6 mass $\%$ of MMT/PNX did not cause any changes in the glass transition temperature. Introduction of 9 mass\% of MMT/PNX mixture shifted $T_{\mathrm{g}}$ to lower temperature range, what is again most probably caused by the addition of organophosphorus flame retardant, Fyrol PNX, which plasticizes the elastic polyurethane foams. The plastifying effect of PNX on f-PUF may be noticed also in the case of temperature dependence of storage modulus curves. The addition of this organophosphorus compound (6-9 mass $\%$ ) decreased $E^{\prime}$ modulus in the whole range of temperatures analyzed.

In the case of modification of f-PUFs using m-MMT, the shift in the glass transition temperature to the higher temperature range may be noticed, what can be attributed to the presence of montmorillonite, which enhanced the rigidity of modified material. Similar effect, manifesting in initial increase of $E^{\prime}$ up to certain amount of nanoclay and the decrease after reaching this content, was previously observed [37]. In the case of modification with m-MMT, higher values of elastic modulus were observed, what may be associated with better dispersion of modified nanoclay in polyurethane matrix due to better parting of silicate layers (greater intergallery space). The increase of elastic constant as an effect of improvement of nano-silicate dispersion was also previously noticed [38, 39]. It can be also noticed that the addition of the MMT nanofiller caused the decrease of damping peak (in the case of higher nanofiller content), but in modified montmorillonite (using PNX), this effect is reduced (Table 4).

Thermogravimetric analyses and flammability

The effects of the m-MMT and MMT/PNX on the thermal stability of the resulting foams were assessed by TG and derivative thermogravimetric analysis. The results obtained 

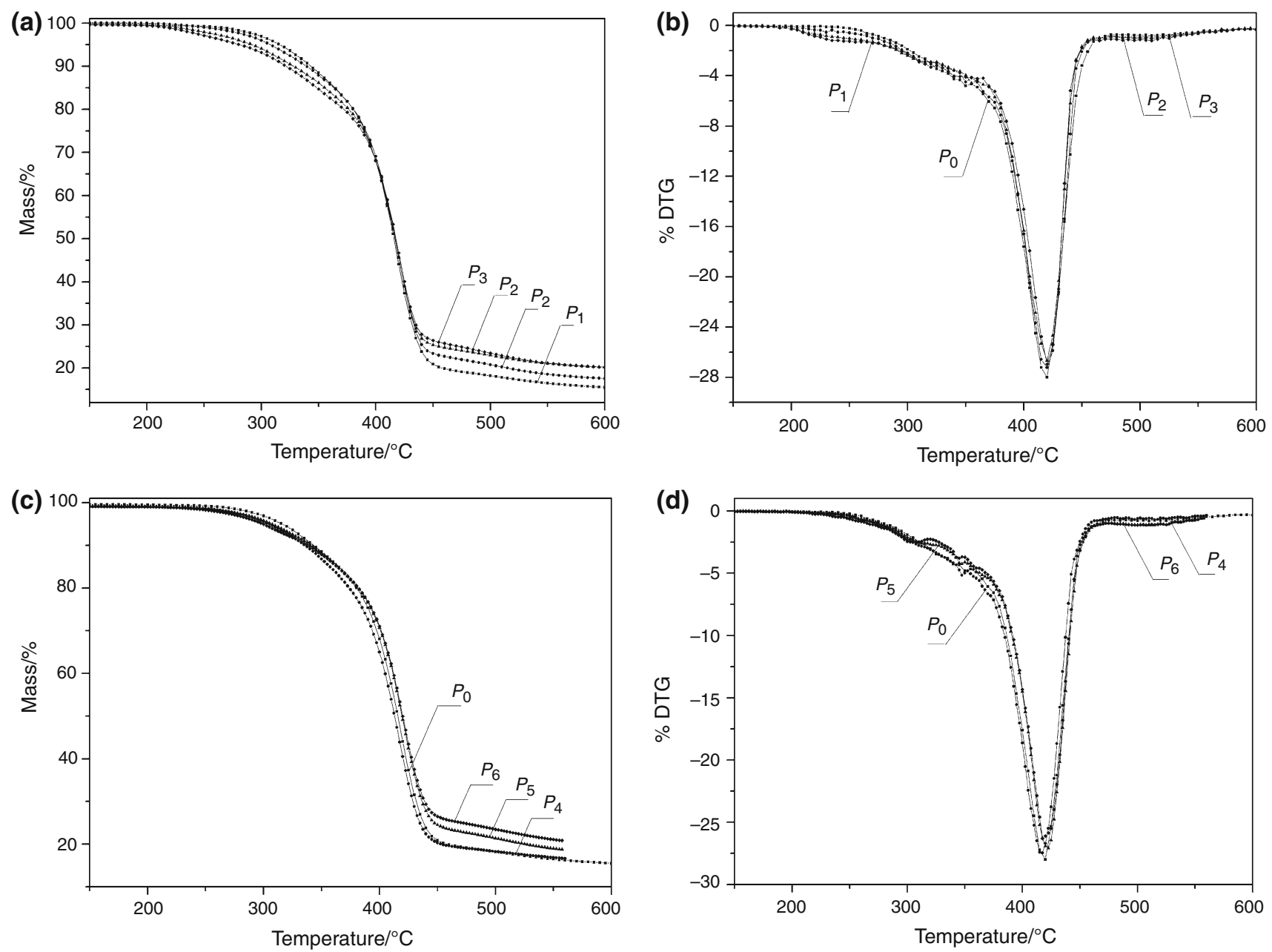

Fig. 6 The effect of MMT/PNX a, b and m-MMT c, d content on mass loss and differential thermogravimetric curve as a function at temperature for pure foam and nanocomposite foams

Table 5 Temperatures of 2, 5, $10 \%$ mass loss and fastest decomposition $\left(T_{\max }\right)$, residual mass and flammability class for the different samples

\begin{tabular}{lllllll}
\hline Sample & $\begin{array}{l}T_{2} / \\
{ }^{\circ} \mathrm{C}\end{array}$ & $\begin{array}{l}T_{5} / \\
{ }^{\circ} \mathrm{C}\end{array}$ & $\begin{array}{l}T_{10} / \\
{ }^{\circ} \mathrm{C}\end{array}$ & $\begin{array}{l}T_{\max } / \\
{ }^{\circ} \mathrm{C}\end{array}$ & $\begin{array}{l}\text { Residual } \\
\text { mass/\% }\end{array}$ & $\begin{array}{l}\text { Flammabilitylin } \\
\text { UL-94 test }\end{array}$ \\
\hline$P_{0}$ & 268 & 316 & 343 & 418 & 15 & $-*$ \\
$P_{1}$ & 275 & 307 & 339 & 419 & 17 & $-*$ \\
$P_{2}$ & 249 & 292 & 328 & 418 & 20 & $-*$ \\
$P_{3}$ & 236 & 280 & 321 & 419 & 20 & $-*$ \\
$P_{4}$ & 268 & 304 & 356 & 416 & 16 & $-*$ \\
$P_{5}$ & 267 & 307 & 341 & 422 & 18 & $-*$ \\
$P_{6}$ & 258 & 299 & 338 & 418 & 20 & $-*$ \\
\hline
\end{tabular}

* The burning characteristics did not allow the V-rating

for the flexible polyurethane nanocomposite foams, investigated in nitrogen atmosphere, are presented in Fig. 6. The temperatures of $2,5,10 \%$ mass loss $\left(T_{2}, T_{5}\right.$, $T_{10}$ ), the temperature of maximum rate of decomposition
( $\left.T_{\max }\right)$, and the residual mass for the nanocomposites foams are summarized in Table 5.

The modification of elastic polyurethane foams using 6-9 mass\% of MMT/PNX as well as using 9 mass\% of m-MMT caused the decrease in the thermal stability of thus obtained materials when compared to unmodified f-PUF. The addition of 3-6 mass $\%$ m-MMT did not caused changes in the temperature of $2 \%$ mass loss. Foams with greater amount of Fyrol PNX $\left(P_{2}, P_{3}\right.$ i $\left.P_{6}\right)$ are characterized by lower initial degradation temperature $\left(T_{2}\right)$ in the case of both-PNX/MMT and m-MMT additives, and then for unmodified system. This effect may be explained by the evaporation of low-molecular compounds present in flame retardant. During the vaporization, these species absorb heat, what causes smaller loss of mass in the higher temperature range comparing to systems which were not modified using PNX/MMT. Similar effects associated with the use of organophosphorus flame retardant were observed previously [31]. 
Flammability of the foams was tested using UL-94 vertical burning test. According to the results obtained, the flammability class could not be assigned since tested materials either burned completely or finished burning in time, which did not allow the V-rating. The results also indicate that introduction of nanofillers reduces flaming drips and the speed rate of the process of composite burning [26, 33].

\section{Conclusions}

Nanocomposites based on flexible polyurethane matrix and filled using montmorillonite organically modified with organophosphorus flame retardant compound were synthesized and analyzed. Modification of PUF using montmorillonite and organophosphorus flame retardant was carried out by the direct addition to polyol mixture the mixture of MMT with PNX (MMT/PNX) or previously modified montmorillonite using PNX (mMMT).

The density of elastic PUFs increases with the increasing content of nanofiller. The biggest increase in apparent density was observed in the case of f-PUF modified with MMT/PNX. The addition of 9 mass $\%$ of modifier caused the rise of apparent density as much as $11 \mathrm{~kg} \mathrm{~m}^{-3}$ compared to unmodified system.

Elastic PUFs modified using 3 mass\% of MMT/PNX and m-MMT possess improved mechanical properties such as elongation at break and the tensile strength. The improvement in $T$ sb of foam modified using 3 mass $\%$ of m-MMT comparing to pure PUF is $27 \mathrm{kPa}$.

The glass transition temperatures of foams modified with 3-6 mass \% of the fillers did not differ from the PUF. However, introduction of 9 mass $\%$ of PNX/MMT shifted the $T_{\mathrm{g}}$ to lower temperature range, while the use of m-MMT caused opposite effect (the $T_{\mathrm{g}}$ was shifted to higher temperature range).

The addition of 3-6 mass $\%$ m-MMT did not caused changes in the temperature of $2 \%$ mass loss. The modification of elastic polyurethane foams using 6-9 mass\% of MMT/PNX as well as using 9 mass\% of m-MMT caused the decrease in the thermal stability of thus obtained materials when compared to unmodified f-PUF.

Burning characteristics of foams containing m-MMT and MMT/PNX did not allow the V-rating according to the UL-94 test.

Finally, the addition of organophosphorus flame retardant caused changes characteristic for plasticizing agents. Open Access This article is distributed under the terms of the Creative Commons Attribution License which permits any use, distribution, and reproduction in any medium, provided the original author(s) and the source are credited.

\section{References}

1. Alexandre M, Dubois P. Polymer-layered silicate nanocomposites: preparation, properties and uses of a new class of materials. Mater Sci Eng R Rep. 2000;28:1-63.

2. Sinha RS, Okamoto M. Polymer/layered silicate nanocomposites: a review from preparation to processing. Prog Polym Sci. 2003;28:1539-641.

3. Lorenzetti A, Hrelja D, Besco S, Roso M, Modesti M. Improvement of nanoclays dispersion through microwave processing in polyurethane rigid nanocomposite foams. J Appl Polym Sci. 2010;115:3667-74.

4. Liang K, Shi ShQ. Nanoclay filled soy-based polyurethane foam. J Appl Polym Sci. 2011;119:1857-63.

5. Zeng QH, Yu AB, Lu GQ, Paul DR. Clay-based polymer nanocomposites: research and commercial development. J Nanosci Nanotechnol. 2005;5:1574-92.

6. Lebaron PC, Wang Z, Pinnavaia T. Polymer-layered silicate nanocomposites: an overview. J Appl Clay Sci. 1999;15:11-29.

7. Luo JJ, Daniel IM. Characterization and modeling of mechanical behavior of polymer/clay nanocomposites. Compos Sci Technol. 2003;63:1607-16

8. Lu C, Mai Y. Influence of aspect ratio on barrier properties of polymer-clay nanocomposites. Phys Rev Lett. 2005;95(8):88303-7.

9. Kim BK, Seo JW, Jeong HM. Morphology and properties of waterborne polyurethane/clay nanocomposites. Eur Polym J. 2003;39:85-91.

10. Morgan AB, Harris RH, Kashiwagi T, Chyall LJ, Gilman JW. Flammability of polystyrene layered silicate (clay). nanocomposites: carbonaceous char formation. Fire Mater. 2002;26:247-53.

11. Zhao CG, Qin HL, Gong FL, Feng M, Zhang SM, Yang MS. Mechanical, thermal and flammability properties of polyethylene/ clay nanocomposites. Polym Degrad Stab. 2005;87:183-9.

12. Fermeglia M, Ferrone M, Pricl S. Computer simulation of nylon6/organoclay nanocomposites: prediction of the binding energy. Fluid Phase Equilib. 2003;212:315-29.

13. Javni I, Song K, Lin J, Petrovic ZS. Structure and properties of flexible polyurethane foams with nano-and micro-fillers. J Cell Plast. 2011;47:357-72.

14. Leszczynska A, Njuguna J, Pielichowski K, Banerjee JR. Polymer/montmorillonite nanocomposites with improved thermal properties: part I. Factors influencing thermal stability and mechanisms of thermal stability improvement. Thermochim Acta. 2007;453:75-96.

15. Wang L, He X, Wilkie CA. The utility of nanocomposites in fire retardancy. Materials. 2010;3:4580-606.

16. Rosato DV, Rosato MV. Plastic product material and process selection handbook. Oxford: Elsevier; 2004. p. 333-69.

17. Harikrishnan G, Singh SN, Kiesel E, Macosko CW. Nanodispersions of carbon nanofiber for polyurethane foaming. Polymer. 2010;51:3349-53.

18. Piszczyk Ł, Strankowski M, Danowska M, Haponiuk JT. Preparation and characterization of rigid polyurethane-polyglycerol nanocomposite foams. Eur Polym J. 2012;48:1726-33.

19. Chang JH, Ukan Y. Nanocomposites of polyurethane with various organoclays: thermomechanical properties, morphology, and gas permeability. J Polym Sci Part B Polym Phys. 2002;40:670-7.

20. Tortora M, Gorrasi G, Vittoria V, Galli G. Structural characterization and transport properties of organically modified montmorillonite/ polyurethane nanocomposites. Polymer. 2002;43:6147-57.

21. Chattopadhyay DK, Webster DC. Thermal stability and flame retardancy of polyurethanes. Prog Polym Sci. 2009;34:1068-133.

22. Qin H, Su Q, Zhanga S, Zhao B. Thermal stability and flammability of polyamide $66 /$ montmorillonite nanocomposites. Polymer. 2003;44:7533-8. 
23. Choi WJ, Kim SH, Kim YJ, Kim SC. Synthesis of chain-extended organifier and properties of polyurethane/clay nanocomposites. Polymer. 2004;45:6045-57.

24. Cervantes JM, Moo Espinosa JI, Cauich-Rodriguez JV, Avila-Ortega A. TGA/FTIR studies of segmented aliphatic polyurethanes and their nanocomposites prepared with commercial montmorillonites. Polym Degrad Stab. 2009;94: 1666-77.

25. Mishra AK, Chattopadhyay S, Rajamohanan PR, Nando GB. Effect of tethering on the structure-property relationship of TPU-dual modified laponite clay nanocomposites prepared by ex-situ and in situ techniques. Polymer. 2011;52:1071-83.

26. Berta M, Lindsay C, Pans G, Camino G. Effect of chemical structure on combustion and thermal behaviour of polyurethane elastomer layered silicate nanocomposites. Polym Degrad Stab. 2006;91:1179-91.

27. Leszczyńska A, Njuguna J, Pielichowski K, Banerjee JR. Polymer/montmorillonite nanocomposites with improved thermal properties: part I. Factors influencing thermal stability and mechanisms of thermal stability improvement. Thermochim Acta. 2007;453:75-96.

28. Leszczyńska A, Njuguna J, Pielichowski K, Banerjee JR. Polymer/montmorillonite nanocomposites with improved thermal properties: part II. Thermal stability of montmorillonite nanocomposites based on different polymeric matrixes. Thermochim Acta. 2007;454:1-22.

29. Hartwig A, Putz D, Schartel B, Bartholmai M. Combustion behaviour of epoxide based nanocomposites with ammonium and phosphonium bentonites. Macromol Chem Phys. 2003;204: $2247-57$.
30. Bartholmai M, Schartel B. Layered silicate polymer nanocomposites: new approach or illusion for fire retardancy? investigations on the potential and on the tasks using a model system. Polym Adv Technol. 2004;15:355-64.

31. Toldy A, Harakály Gy, Szolnoki B, Zimonyi E. Flame retardancy of thermoplastics polyurethanes, Polym. Degrad Stab. 2012;97:2524-30.

32. Harikrishnan G, Patro TU, Khakhar DV. Reticulated vitreous carbon from polyurethane foam-clay composites. Ind Engg Chem Res. 2006;45:7126-34.

33. Widya T, Macosko CW. Nanoclay-modified rigid polyurethane foam. J Macromol Sci Phy. 2005;44:897-908.

34. Chavarria F, Paul DR. Morphology and properties of thermoplastic polyurethane nanocomposites: effect of organoclay structure. Polymer. 2006;47:7760-73.

35. Kim SH, Lee MC, Kim HD, Park HC, Jeong HM, Yoon KS, Kim BK. Nanoclay reinforced rigid polyurethane foams. J App Polym Sci. 2010;117:1992-7.

36. Chuayjulijt S, Maungchareon A, Saravari O. Preparation and properties of palm oil-based rigid polyurethane nanocomposite foams. Reinf Plast Compos. 2010;29:218-25.

37. Czarnecka-Komorowska D, Tomczyk T. Badania wpływu nanonapełniacza na właściwości mechaniczne recyklatów gumowych. Arch Technol Masz I Autom. 2008;28:145-52.

38. Herrera-Alonso JM, Marand E, Little JC, Cox SS. Transport properties in polyurethane/clay nanocomposites as barrier materials: effect of processing conditions. J Memb Sci. 2009;337:208-14.

39. Seo WJ, Sung YT, Kim SB, Lee YB. Effects of ultrasound on the synthesis and properties of polyurethane foam/clay nanocomposites. J Appl Polym Sci. 2006;102:3764-73. 